\title{
MR. JUSTICE JOHN HOWARD SISSONS
}

\author{
W. G. MORROW*
}

On September 14, 1955, Chief Judge John Howard Sissons, as he then was, was appointed Judge of the Territorial Court of the Northwest Territories. ${ }^{1}$ This date is important in the history of the administration of Justice in Canada because for the first time provision was made for a full time Judge with all the powers of a Superior Court Judge to serve Canada's vast northern region. Shortly afterwards Justice Sissons was made a Deputy Judge of the Yukon Territory, but it will be as a Judge of the Territorial Court of the Northwest Territories that he will be best remembered.

Justice Sissons describes himself as "rough, tough, crusty and unorthodox." Not all who knew him will agree with the appellations "rough" and "crusty" but all will attest to the other two. Born and raised at Orillia, Ontario, as a Scotch Presbyterian (he was later to become an Anglican), he early learned to hold his end up in life, as he overcame a limp, caused by infantile paralysis while an infant. His refusal to let this slow him up in any way, has undoubtedly helped mould his character-and to develop in him a strong will and determination to overcome any opposition or hurdle-physical, legal or administrative.

Following a variety of work, from acting as stenographer, office clerk and as teacher, he eventually graduated from Queen's in 1917 with an Honours Degree in Political Science and Economics. He became a member of the Alberta Bar in 1921.

It is perhaps not without some significance, in the light of his later development, that the embryo lawyer during the articling period studied under such Alberta pioneers and leaders in law as G. H. Steer, Q.C., C. A. Grant Q.C., and S. H. McCuaig, Q.C.

A law practice in the City was not enough challenge to the young lawyer. He chose the Peace River country as his territory, and eventually entered into partnership with the late T. A. Lawlor, Q.C.-a happy association that continued in Grande Prairie for 25 years.

Almost from the start, the young lawyer became completely immersed in the problems of the new community and in its politics. This led him to the House of Commons for the period 1940-1945-carrying the Liberal standard. It was during this period of his life that "Jack" Sissons had his first contact with Indians and Metis, and their problems. His experience here, and his appreciation of their problems and their way of life, and his early championing of their right to be considered as full Canadians, prepared him well for the role he was to follow later as the new Territorial Judge.

Mention should be made that during this busy time, "Jack" Sissons did, in 1929, find time to marry Frances Hewitt Johnson. There can be

- The Honourable Mr. Justice W. G. Morrow, Judge of the Territorial Court of the Northwest Territories.

1 The Northwest Territories Act, R.S.C. 1952, c. 331, s. 20 (1). 
no doubt that Frances Sissons over the years that have followed became, and has remained a full part of the Judge's strength. Those who, like the writer, have had the good fortune to enjoy her generous hospitality and to observe her charm will certainly attest to the above.

While at Ottawa as Member of Parliament Justice Sissons was one of those instrumental in initiating a Judicial Inquiry to inquire into the conditions of the Indians of Lesser Slave Lake. The tone of his speeches in Parliament at this time never failed to show faith in the ultimate future of the North.

When the Northwest Territories Act was amended to provide for a Judge on a full time basis, the invitation to accept the obvious challenge offered would hardly have been turned down. Justice Sissons was sixty-three years old at this time but once again he and his charming wife were prepared to go "pioneering".

Upon leaving Lethbridge to go to Yellowknife Justice Sissons expressed what he thought a Judge should be: He said the man to qualify should:

(a) Desire to be of service.

(b) Be willing to work.

(c) Have common sense.

(d) Show patience and courtesy.

(e) Show a careful regard for facts and have the ability to assess them.

(f) Have a knowledge of elementary law.

In his eleven or more years in the North as a Judge, he practised what he preached and assiduously lived up to his own tests. In the writer's opinion, however, he left out one important qualification-"courage". The courage or the will to pronounce his judgment as the facts and law warranted and as his conscience dictated, regardless of whether the result might be popular or not. Undoubtedly this was one of his greatest attributes.

Justice Sissons did not sit comfortably at Yellowknife, and make the litigants come to him. Instead he became, and insisted on being a truly itinerant Court-he took the Court to every corner of the Northern regions. Indians, Eskimos, or Whites had their "day in court" in their home area, and when it meant a jury trial, all were tried by their "peers" in the tradition of the Magna Carta. This took a great deal of determination and courage. It came only after many fights with "higher authority", at great personal inconvenience and discomfort to the Judge, and not without considerable danger and risk. But the "new" Judge eventually triumphed, with the result that by the time of his retirement, the itinerant way of Justice and "his brand" of Justice had become accepted and is now accepted by all. The present article is not intended to further describe the more adventurous and perhaps more exciting side of the life of Judge Sissons on circuit, but to mention briefly a few of his more important legal decisions.

Two threads, above all others, are to be found woven into every one of Judge Sissons' judgments. A study of his many charges to the 
Jury, and an analysis of his many reported judgments will always reveal an emphasis by him on the importance of the burden of proof remaining on the Crown, and how no person should be found guilty if there can be any reasonable doubt. It is not for this survey to go into those cases other than the reported ones, but the theme of proof beyond a reasonable doubt is ever present.

In 1957, an appeal was taken from a Magistrate as a trial de novo in a case involving the Liquor Ordinance. ${ }^{2}$ In order for the Crown to succeed it had to persuade the Court to infer from the amount of liquor the accused had purchased that he must have been keeping it for sale. In this case, Regina v. $K y d,{ }^{3}$ Judge Sissons expressed his abhorrence of any deviation from fundamental principles which indicates, as do his other cases, his position that where possible he resisted any further whittling away of fundamental protections. In this judgment he states:

It is apparent from reported cases that the provincial Acts are regarded as offending against the fundamental principles of British justice, viz, that an accused person is presumed to be innocent until he proved guilty, and that he does not have to prove his innocence; and that the burden of proof in a criminal case is always on the Crown, and that the accused must be proved guilty beyond a reasonable doubt. I do not myself think that the Liquor Ordinance of the Northwest Territories offends on the whole in that regard.4

He later states:

One must be most careful in drawing an inference in a criminal case. It must not be a mere guess or suspicion. A man is not to be convicted on a guess, however shrewd that guess may be. It must be an inference which the mind naturally and logically draws from other proven facts. ${ }^{5}$

In this judgment, as in almost everyone of his judgments, we find him turning back to the well known rule in Hodge's Case.

Later in the same year in a case involving the Northwest Territory Fishery Regulations, ${ }^{6}$ " the Crown is reminded of its fundamental burden. This treatment was particularly noticeable when the accused was an Indian or an Eskimo. There is no doubt that Judge Sissons took the position that these people in the Territories had neither the sophistication nor the opportunity to fully appreciate their rights. Indeed, they did not know what was happening to them when they found themselves in the toils of the law. $\mathrm{He}$ is at his very best here in his insistence that they, of all people, understand what is taking place, and that never, if it can be helped, will one of them feel the might of the law unless he has been proven to have been guilty beyond any reasonable doubt.

One of the earliest reported decisions involving an Indian is Regina v. Modeste, ${ }^{8}$ where an Indian was charged under the Indian Act $^{9}$ with being unlawfully intoxicated off a reserve. In allowing an appeal which had the effect of setting aside a conviction, the Judge concluded by stating: "None of the three elements of the offence has been established beyond a reasonable doubt." ${ }^{10}$ It is of interest that in this case he

2 R.O. N.W.T. c. 60.

3 (1957), 23 W.W.R. 642.

4 Id., at 645 .

Id., at 648 .

61932 , c. 42, d. 1

7 Regina v. Turnet (1957), 24 W.W.R. 529, 532.

8 (1959), 31 W.W.R. 84.

9 R.S.C. 1952 , c. 149

10 Ante, n. 8, at 88. 
takes one of his earliest "stabs" at the Dominion Government for its failure to carry out the terms of its Treaties with the Indians, when he suggests that an Indian could not be intoxicated off a reserve where the Government has not yet set up reserves in the Territories.

Under this heading reference should be made to Judge Sissons' approach to a plea of "guilty" by natives, particularly by Eskimos. It was his understanding that "guilty" or "not guilty" had no equivalent in the Eskimo language. Accordingly if there was any hesitation in a plea the Judge would record it as "not guilty" and proceed with a trial.

His opportunity to comment on the practice of taking "guilty" pleas without care came in 1963 in a case involving the killing of a musk-ox.11 An Eskimo was brought before a Justice of the Peace who was also Area Administrator and Game Warden. The prosecuting constable was also the informant. On being asked to plead, the Eskimo hesitated. The Justice of the Peace then asked him, through an interpreter, if he did it. Upon the native saying "yes I did this", the Justice of the Peace then proceeded to treat it as a guilty plea. Investigation showed that the accused killed the musk-ox to defend himself and the community. As a result of Judge Sissons' digging into the circumstances the Crown moved by certiorari to set aside the conviction. Judge Sissons is very outspoken and critical of the administration of justice in the north in his judgment in this case. Among other things he states:

He was deprived of the right to a fair hearing in accordance with principles of fundamental justice.

He remarks later:

It was not necessary for the accused to show conclusively that the killing of the musk-ox was necessary to save the camp or avoid serious harm to the Eskimos. He was entitled to an acquittal if upon all the evidence there was a reasonable doubt whether or not the killing of the musk-ox was under reasonable apprehension of grievous harm to the camp and if he believed on reasonable grounds that he could not otherwise preserve himself or the camps from grievous harm.

One of the Judge's most important fields was in his jealous fight to protect and nurture the customs and habits of the native people and in particular of the Eskimo. Judge Sissons had no hesitation in taking the position that he was there to protect these people and to help them preserve their culture and way of life. If they were eventually to become engulfed in our so-called 20th Century civilization he would at least attempt to slow the process, to at least make the transition from a stoneage type of civilization less painful. Whenever therefore there was conflict between the modern legislation and laws, and the native custom and habit, the Court's approach was one of "reserve".

This approach is best observed in two reported judgments, one on adoption and the other on marriage. To bring the message home the Judge often used strong language against the powers that be, stronger than one normally expects to find in judicial pronouncements. But then Judge Sissons knew that perhaps of all the white persons in the Territories he was the oniy one who could "safely" speak out without risk of discipline or economic sanction.

11 Regina v. Koonungnak (1963), 45 W.W.R. 282.

12 Id., at 298. 
The first case was Re Katie's Adoption Petition, ${ }^{13}$ where he stated: ${ }^{14}$

The Eskimos, and particularly those in outlying settlements and distant camps, are clinging to their culture and way of life which they have found to be good. These people are in process of cultural change and have a right to retain whatever they like of their culture until they are prepared of their own free will to accept a new culture. In particular, although there may be some strange features in Eskimo adoption custom which the experts cannot understand or appreciate, it is good and has stood the test of many centuries and these people should not be forced to abandon it and it should be recognized by the Court.

He goes on to review the various "paper" and other requirements laid down by the Adoption Ordinance, ${ }^{15}$ which practically make it impossible for an average Eskimo couple to comply with the Ordinance, and states: ${ }^{10}$

This is generally an impractical provision so far as Eskimos are concerned. At most points there is no regular mail service and mail goes in or comes out by chance, perhaps once or twice a year. The ordinary Eskimo cannot read or write. The superintendent is far away. There is usually locally no one in authority, or perhaps within 500 miles, who could be notified, even if such notification would be sufficient.

It is a shocking provision which makes it a crime for an Eskimo to follow his ancient custom in the traditional way.

To sum it up, he then fell back on Section 17 of the Northwest Territories Act, wherein "the laws of England . . . a as such laws existed on the 15th day of July, 1870, shall be in force in the Territories . . .." and construed them as permitting the recognition of native custom. ${ }^{17}$

Shortly afterwards he ran head-on into "departmental obstructionism", as he was wont to call it, in respect to Eskimo marriages. The case here was Re Noah Estate. ${ }^{18}$ This case had the effect of holding that a marriage in accordance with Eskimo custom is valid.

Some of his remarks commencing at page 590 of the report are of interest:

As I understand Northern Affairs' "supplementary argument", supra, it is submitted that a marriage in accordance with Eskimo custom is not a marriage, it is simply "the Eskimo custom of concubinage."

I feel that I must deal with the argument as I consider it casts unwarranted aspersions on Igah and Noah and on Eskimos.

The supplementary argument is fanciful and scandalous, both as regards to the Eskimos and as regards Noah and Igah.

A marriage in accordance with Eskimo custom is not the Eskimo custom of concubinage.

Igah was not a concubine. Noah was not a paramour. And he was not a philanderer.

Marriage among the Eskimos is not, as suggested by the argument, a morally loose affair.

Morality pertains to or is concerned with right conduct and it is generally accepted custom of conduct and right living in one's own society which govern. It may be that in spite of our conceits that customs other than our own may be generally accepted or condoned in other societies, and may even be more moral. The sexual customs of the Eskimos may be different from ours, but that does not constitute immorality.

Eskimos have their own code of morality and adhere very strictly to this, not only for its own sake but for the good of their society, and punish transgressors in their own effective way. The standard of morality among the Eskimos at Broughton Island is very high.

13 (1961), 38 W.W.R. 100.

14 Id., at 101 .

15 N.W.T.O. 1956, c. 1

16 Ante, n. 13, at 104.

17 R.S.C. 1952, c. 331 .

18 (1961), 36 W.W.R. 577. 
In 1959, Judge Sissons wrote a judgment in a matrimonial case which, if the Court of Appeal had not insisted in following a "traditional" approach to the doctrine of domicile, might have had a revolutionary effect on the development of law in Canada. It might even be said that this, his judgment, could have solved to some extent the problem of divorce for Canada and would have introduced the concept of a Canadian domicile. The case was Voghell v. Voghell and Pratt. ${ }^{19}$ The facts are not important except to say that the plaintiff husband was clearly domiciled in Alberta and had sued for custody of his children as well as for other relief, coming to the Territorial Court for his forum, the wife being a resident in the Northwest Territories.

At the beginning of his judgment Judge Sissons comes out with a remark that is characteristic of his forthright nature where he states. ${ }^{20}$

These difficulties are due in large measure to the anomalous position and jurisdiction of this court and the antiquated and inadequate laws and ordinances of the Northwest Territories in regard to domestic relations matters.

He reviews the history of the judicial decisions relating to provincial domicile commenting that: "It is questionable just how solidly this rule has been established." He refers to Mr. Kent Power's remarks: "21 "Is it not now open to the present highest court in this country to decline to follow the Cook case?", and then in assessing the position with respect to the Northwest Territories (not a province) he concludes: ${ }^{22}$

It is certainly unrealistic to suggest that as in the Cook case the provinces of Alberta and Ontario are "two sovereign states" or that in the present case the province of Alberta and the Northwest Territories are "two sovereign states" or that this court is an "independent authority."

In the end result he granted a divorce to the defendant wife.

The case, of course, went to appeal. It might have been open to the Appeal Court to consider the possibility of a Canadian domicile in the case of a resident of the Northwest Territories. In its judgment however $^{23}$ this Court took the traditional approach and treated the Northwest Territories as another province for purposes of divorce and domicile. The late Justice H. J. Macdonald stated the position in this way: ${ }^{24}$

It follows that in order for a person to invoke the jurisdiction of the courts of the Northwest Territories for the purpose of divorce, that person must establish that he or she is domiciled there, or in case of a married woman seeking a divorce, that she comes within the exception provided by the Divorce Jurisdiction Act.

An attempt was made to take the case higher, to invite the Supreme Court of Canada to "decline to follow the Cook case" in the words of Kent Power, but that Court refused to allow leave to appeal. ${ }^{25}$

It is interesting to note that the ultimate question of custody, notwithstanding the above decision, was resolved by $\mathrm{Mr}$. Justice Bastin of the Manitoba Queen's Bench Court who chose to differ and gave the custody to the mother." The determined Mrs. Voghell demonstrated

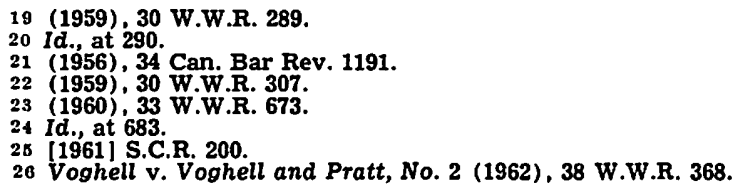


her staying power and obtained final victory in the Alberta Court obtaining a divorce from her husband in that forum about a year later.

As the first Judge in the newly constituted Territorial Court Judge Sissons considered that he was the master of his own practice. He never hesitated to operate, if necessary, in conflict with recognized legal practice if the local conditions in his large and primitive territory dictated the need for a modified practice and procedure, and if the ultimate ends of justice required it. In the Voghell case $^{2 \tau}$ we find an expression of his philosophy in this regard:

Furthermore, this court is master of its own practice and, having regard to special circumstances in the Northwest Territories, deems that it can and should exercise jurisdiction where the husband is domiciled anywhere in Canada and either party is bona fide resident in the Northwest Territories.

Under the same heading it should be observed that he applied his. practical knowledge and experience gained first hand, in the sentencing of accused persons, particularly natives, who came before him. Recognizing that Eskimos for example had a shorter life span than whites, and that incarceration in prison away from home might result in the prisoner's ultimate death, he made a firm practice of discounting the length of sentence in proportion to the relative life-span of the person concerned. His practice received the seal of approval from the Court of Appeal in the first case to come before that newly constituted Court, R. v. Ayalik, ${ }^{28}$ where the late Justice H. J. Macdonald in giving the decision of the Court stated: ${ }^{20}$

However it should be noted that in the present case the learned trial judge had a distinct advantage over the members of the court for with his wide experience in the far-flung areas of the extensive jurisdiction of the trial division of this court he has knowledge of local conditions, ways of life, habits, customs and characteristics of the race of people of which the accused is a member.

This case has been consistently followed.

Judge Sissons became better known in respect of his treatment of the hunting rights of the native peoples-both Indian and Eskimo. The inevitable clash between the time-honoured way of life of these peoples and the new 20th Century way of life is graphically recounted for all time in the judgments of this Judge-determined at all costs to protect them and to try to get them a "fair deal", and to bring home to the powers that be that "their" (Native) rights had been ignored. It is in this sphere, alas, where he has been the least successful in the sense of lasting legal precedent. It may be observed, however, that while he appears to have "lost" almost every battle he has undoubtedly "won" the the war, in the sense of an aroused public conscience.

One of his earliest decisions under this heading is Regina v. Kogolak ${ }^{30}$ which dealt with the killing of a musk-ox by an Eskimo. In this decision the Judge shows his diligent research, following through the various statutes, ordinances, and treaties dealing with Indians and native peoples going as far back as the Royal Proclamation of 1763 . In his judgment he states that the Proclamation "is the only Bill of Rights

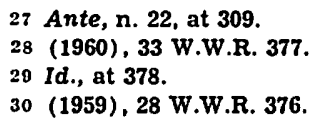


the Eskimos have as Eskimos." ${ }^{31}$ Later, $^{32}$ he adopts the reasoning in $R$. v. Wesley ${ }^{33}$ and concludes that the "position of the Eskimos is stronger" than that of Indians. This case, decided before the Canadian Bill of Rights became law, contains this interesting observation. ${ }^{34}$

In these days when there is much talk of a Canadian Bill of Rights it is well to keep in mind the rights of the Eskimos. Talk of a new Canadian Bill of Rights would be rather strange and futile if at the same time we treat the old Eskimo Bill of Rights as a dead letter.

It was the "duck case," 35 however, which brought the Judge's battle for Indian Rights into the limelight. This was in 1962 . Judge Sissons here dealt with the Indians and their Treaty Rights and the conflict with the provisions of The Migratory Birds Convention Act. By now, in addition to the $R$. v. Wesley case ${ }^{36}$ the Judge had the new Canadian Bill of Rights ${ }^{37}$ to rely on.

The Sikyea case went to the Court of Appeal where Judge Sissons was reversed although that Court recognized that the Government of Canada did abrogate the treaty rights. In delivering judgment Justice H. G. Johnson stated: ${ }^{38}$

It is, I think, clear that the rights given to the Indians by their treaties as they apply to migratory birds have been taken away by this Act and its regulations.

On further appeal the Supreme Court of Canada ${ }^{30}$ upheld the Court of Appeal. ${ }^{40}$

It is interesting to read the remarks of Mr. Justice Cartwright in the Ontario "duck case" which came along shortly afterwards."1

I think that if the view of the effect of s. 87 which appears to me to be decisive in the case at bar had been considered in the Court of Appeal or in this Court in the Sikyea case it would have been examined and dealt with in the reasons delivered. I do not propose to enter on the question, which since 1949 has been raised from time to time by authors, whether this Court not that it has become the final Court of Appeal for Canada is, as in the case of the House of Lords, bound by its own previous decisions on questions of law or whether, as in the case of the Judicial Committee or the Supreme Court of the United States, it is free under certain circumstances to reconsider them. I find it unnecessary to do this. Assuming for the purposes of this appeal that we are governed by the rule of stare decisis, it appears to me that the judgment in Sikyea falls within one of the exceptions to that rule in that it was given per incuriam. ${ }^{11}$

Almost at the same time, a more general attack on the hunting rights, in the legal sense, was emerging in respect to the Game Ordinance. The first of these cases is Kallooar v. Regina ${ }^{42}$ where Judge Sissons found that an amendment to the Northwest Territories Act ${ }^{43}$ had the effect of preventing the Game Ordinance ${ }^{44}$ from applying to Eskimos.

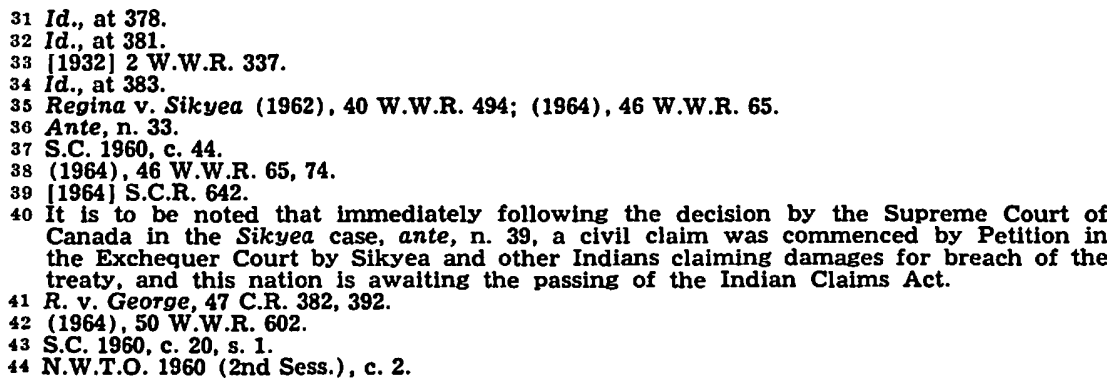


The same point came up in a similar case involving Eskimo hunting rights and the abandonment of game. This case Regina v. Sigeareak ${ }^{45}$ was decided by Judge Sissons in the same way as Kallooar but this time the Crown appealed. The Appeal Court reversed Judge Sissons ${ }^{40}$ and this judgment on appeal to the Supreme Court of Canada was upheld.47 A careful reading of this judgment shows that almost every one of the grounds upon which Judge Sissons had founded his judgments in favour of the natives, were being abrogated. The Royal Proclamation of 1763 was held to have no application to the area concerned, and the Game Ordinance was held to apply to Eskimos. The final blow is found where the judgment of the Court states: ${ }^{48}$

I think it is desirable to say specifically that insofar as Regina v. Kallooar and

Regina v. Kogogolak hold that the Game Ordinance does not apply to Indians or Eskimos in the Northwest Territories, they are not good law and must be taken as having been overruled.

Justice Sissons in the short span of some eleven years became not only a legend in the territories over which he presided as a Justice, but set the pattern to be followed by his successors in office. The sympathy and deep understanding he showed for the problems of the people who came before him, and particularly the native people, has evoked a response in the people and Government of Canada that cannot be allowed to die out. It is doubtful if Canada will producc a more colorful figure in the legal sense in the years ahead and one would be hard put to name a more colorful one from the years past. 